Leszek Szewczyk $^{1}$

Uniwersytet Śląsi

\title{
Treść przepowiadania do poszukujących Boga na przykładzie listów pasterskich biskupów Francji i Włoch
}

Kościół powszechny dostrzega konieczność systematycznego docierania do osób dystansujących się od Kościoła i religii. Również poszczególne Kościoły lokalne przejawiają inicjatywy mające na celu bezpośredni zwrot do osób niewierzących, jak również wierzących, ale w znacznym stopniu już zsekularyzowanych. Zauważa się też $\mathrm{w}$ dzisiejszej kulturze pewną krytykę postawy misyjnej wobec tych, którzy nie wierzą bądź wyznają inną wiarę ${ }^{2}$. W Nocie doktrynalnej na temat pewnych aspektów ewangelizacji Kongregacja Nauki Wiary stwierdza: „często uważa się, że wszelkie próby przekonywania innych w sprawach religijnych są ograniczaniem wolności”’. Pytanie o istnienie Boga, możliwość nawiązania z Nim kon-

1 Leszek Szewczyk - prezbiter archidiecezji katowickiej, dr hab. nauk teologicznych w zakresie homiletyki, profesor Uniwersytetu Śląskiego, dyplomowany logopeda. Zainteresowania naukowe: teologia przepowiadania słowa Bożego, retoryczny wymiar przepowiadania. E-mail: leszek.szewczyk@interia.pl.

2 W. Osial, Wezwanie Benedykta XVI do nowej ewangelizacji w świetle listu apostolskiego motu proprio „Ubicumque et semper” ustanawiającego Papieską Radę ds. Krzewienia Nowej Ewangelizacji, „Warszawskie Studia Teologiczne” 24 (2011) 1, s. 282.

3 Kongregacja Nauki Wiary, Nota doktrynalna na temat pewnych aspektów ewangelizacji, „L'Osservatore Romano" wyd. pol. 29 (2008) nr 2, s. 50-51. 
taktu i ewentualny wpływ Boga na życie człowieka nurtuje ludzi już od wieków. To charakterystyczna cecha człowieka, który pyta o drugą stronę życia. Także zsekularyzowane społeczeństwo pyta o źródła, z których wywodzą się wizje dotyczące ludzkości, wzajemnego zaufania, więzi społecznej i relacji międzyludzkich.

Próba odpowiedzi na powyższe pytania jest jednym z głównych obowiązków biskupów, w posłudze których miejsce szczególne zajmuje głoszenie słowa Bożego. Biskup powinien obwieszczać ludziom Ewangelię Chrystusową, nawołując ich w mocy Ducha do wiary lub umacniając ich w żywej wierze ${ }^{4}$. Jedną z form nauczania biskupiego, które poruszają sprawy istotne dla Kościoła i społeczeństwa oraz stanowią rodzaj dialogu biskupa z powierzoną mu częścią ludu Bożego, są listy pasterskie ${ }^{5}$. Jest to jeden ze sposobów bezpośredniego zwrotu w stronę osób poszukujących Boga. W niniejszym opracowaniu podjęty zostanie problem treści przepowiadania do poszukujących Boga. W pierwszej części opracowania omówione będzie zagadnienie podstawowego zadania biskupa, którym jest głoszenie słowa Bożego. W dalszej kolejności przedstawione zostaną inicjatywy mające na celu bezpośredni zwrot do osób poszukujących Boga. Przykładem bezpośredniego zwrotu do osób niewierzących, jak również poszukujących Boga mogą być listy biskupów Francji - Proponować wiare we współczesnym społeczeństwie $^{6}$ [dalej: LCF] i Włoch - List do poszukujących Boga ${ }^{7}$ [dalej: LcD]. Omówienie etapów ich powstawania i zarysowanie ogólnej charakterystyki oraz analiza treści będą kolejnymi elementami treści niniejszego opracowania.

4 Sobór Watykański II, konst. Lumen gentium [dalej: KK], dekret Christus Dominus [dalej: DB], 12, 13.

5 Kongregacja Biskupów, instrukcja Ecclesiae imago [dalej: EI].

6 Les Evêques de France, Proposer la foi dans la société actuelle, III. Lettre aux catholiques de France, Paris 1997.

7 Commisione Episcopale per la Dottrina della Fede, L'annuncio e la catechesi della Conferenza Episcopale Italiana, Lettera ai cercatori di Dio, Roma 2009. 


\section{Głoszenie słowa Bożego jako podstawowe zadanie biskupa}

W działalności Kościoła głoszenie Chrystusa stoi zawsze na pierwszym miejscu, biskup zaś jest pierwszym głosicielem Ewangelii słowem i świadectwem własnego życia. Ma być świadom współczesnych wyzwań i umieć stawić im czoło, biorąc na siebie ten obowiązek z mocą i ufnością . Na podstawie uprawnienia własnego, wypływającego z sakramentu święceń, prawo i obowiązek głoszenia słowa Bożego w odniesieniu do całego Kościoła mają biskup Rzymu i kolegium biskupów, zaś w odniesieniu do Kościoła partykularnego - biskup oraz kapłani i diakoni jako jego współpracownicy ${ }^{9}$.

Przepowiadanie zajmuje szczególne miejsce wśród głównych obowiązków biskupów (KK 25), którzy w posłudze głoszenia słowa Bożego mają operować „różnymi dostępnymi w dzisiejszych czasach środkami, przede wszystkim kaznodziejstwem" (DB 13). Biskup powinien obwieszczać ludziom Ewangelię Chrystusową, nawołując ich w mocy Ducha do wiary lub umacniając ich w żywej wierze. To zadanie powinno stać na pierwszym miejscu wśród zasadniczych zadań biskupich (DB 12).

Biskup diecezjalny, sam często głosząc słowo Boże, ma obowiązek przedstawiać wiernym i wyjaśniać prawdy wiary, w które należy wierzyć i stosować w obyczajach. Zadaniem biskupa jest stanowcza obrona jedności i pełnego przekazu wiary oraz osąd, co jest zgodne, a co niezgodne ze słowem Bożym. Biskup ma także obowiązek demaskować fałszywe antropologie, odzyskiwać wartości stłumione procesami ideologicznymi i rozpoznawać prawdę. Jest ważne, aby poza troską o zachowanie prawowiernościgłosił Ewangeliętak, żeby została usłyszanai przyjęta $(P G 29,30)^{10}$.

Biskup ma obowiązek dbać o wierne przekazywanie słowa Bożego i czuwać nad właściwym przekazaniem nauczania moralnego oraz chronić wiernych, przy użyciu stosownych środków, przed wszelkimi

8 Jan Paweł II, adhort. apost. Pastores gregis [dalej: PG], 26.

9 G. Siwek, Przepowiadanie słowa Bożego, w: Teologia pastoralna, t. 1, red. R. Kamiński, Lublin 2002, s. 143.

10 L. Szewczyk, Odnowa przepowiadania słowa Bożego w (archi)diecezji katowickiej po Soborze Watykańskim II. Studium homiletyczne, Katowice 2009, s. 99. 
doktrynami i teoriami, które propagują fałszywe nauczanie ${ }^{11}$. Do nauczycielskich zadań biskupa należy troska o przygotowanie ogólnego planu przepowiadania, troska o nieskażony wykład wiary oraz umożliwienie każdemu spotkania ze słowem Bożym oraz przygotowanie do przyjęcia sakramentów świętych. Biskupowi powierzona jest rola inspiratora, kierownika i koordynatora inicjatyw diecezjalnych zmierzających do jak najszerszego głoszenia Dobrej Nowiny (EI 93-97).

Głównym przedmiotem nauczania biskupiego są tajemnice zbawienia, wypełniające się w Chrystusie jako centrum życia wiernych i całej ludzkiej historii, a także obyczaje chrześcijańskie i teologiczne zasady życia społecznego, będące odpowiedzią Kościoła na konkretną sytuację życiową współczesnego człowieka. W nauczaniu tych prawd biskup powinien kierować się miłością pasterską, prawdy te potwierdzać swoim życiem oraz troszczyć się, aby przebijała przez nie moc słowa Bożego (EI 56, 58; KK 23).

Jako podstawowy typ przepowiadania biskupiego wskazuje się ewangelizację niewierzących, osób, które odstąpiły od wiary lub stojących $\mathrm{z}$ dala od Kościoła ${ }^{12}$. Zasadniczym rysem posługi biskupa ma być jego działalność ewangelizacyjna, która prowadzi ludzi do wiary lub umocnienia ich życia $\mathrm{w}$ wierze $^{13}$. Pierwsze głoszenie kerygmatu, niezbędne do wzbudzenia posłuszeństwa wiary, jest w obecnej sytuacji, naznaczonej obojętnością i ignorancją religijną wielu chrześcijan, szczególnie potrzebne (PG 29).

W działalności apostolskiej Kościoła coraz większą rolę odgrywają konferencje biskupów poszczególnych krajów ${ }^{14}$. Funkcjonowanie kon-

11 Jan Paweł II, enc. Veritatis splendor [dalej: VSp], 116.

12 Paweł VI, adhort. apost. Evangelii nuntiandi, 51-52.

13 L. Szewczyk, Biskup jako nauczyciel wiary i herold słowa Bożego, w: Vobis Episcopus Vobiscum Christianus, red. W. Myszor, A. Malina, Katowice 2004, s. 156-160.

14 Kodeks prawa kanonicznego z 1983 roku definiuje konferencję episkopatu jako „zebranie biskupów jakiegoś kraju lub określonego terytorium, wypełniających wspólnie pewne zadania pasterskie dla wiernych jej terytorium, w celu pomnożenia dobra udzielanego ludziom przez Kościół, głównie przez odpowiednio przystosowane do bieżących okoliczności czasu i miejsca formy i sposoby apostolatu, z zachowaniem przepisów prawa (kan. 447). Konferencje te, jako zebrania biskupów danego kraju, powstały najpierw w Europie w pierwszych dziesiątkach XIX wieku, a potem w innych krajach świata, a ich 
ferencji episkopatów wymaga jeszcze usprawnienia, chociaż uczyniono wiele, „aby jak najlepiej wykorzystać możliwości tych koniecznych instytucji służących komunii, szczególnie ważnych dzisiaj, gdy trzeba szybko i skutecznie rozwiązywać problemy, z jakimi styka się Kościół w niezwykle dynamicznie zmieniającej się rzeczywistości naszej epoki"15. Konferencja episkopatu ma za zadanie wymianę poglądów, możliwość przeprowadzania konsultacji oraz koordynację posługi duszpasterskiej na danym terytorium. „Wychodząc poza granice swojej diecezji, biskupi mają możliwość wspólnego zaradzania problemom regionu obejmowanego działaniem konferencji, podejmując stosowne rozwiązania o charakterze duszpasterskim i doktrynalnym"16.

Zadaniem konferencji biskupich jest służba Kościołowi, a w szczególności Kościołom partykularnym danego terytorium. Wspólne działanie biskupów danej konferencji powinno obejmować między innymi głoszenie oraz obronę wiary i obyczajów ${ }^{17}$. Biskupi zgromadzeni na konferencjach są autentycznymi nauczycielami wiary dla wierzących ${ }^{18}$.

Tak poszczególni biskupi, jak i konferencje episkopatów, zabierając głos w sprawach wiary czy moralności, mogą korzystać z bardzo różnych form i gatunków tekstowych. Wypowiedź taka powinna być możliwie najbardziej czytelna i zrozumiała dla szerokiego kręgu odbiorców, a wola nadawcy wyrażona w sposób jasny i precyzyjny. Do najbardziej

dynamiczny rozwój wiąże się ze wskazaniami Soboru Watykańskiego II, te bowiem nadały im nowy kształt prawny”. J. Dyduch, Kształt prawny Konferencji Episkopatu Polski, „Prawo Kanoniczne" 56 (2013) 2, s. 15.

15 Jan Paweł II, list apost. Novo millennio ineunte, 44.

16 M. Lukoszek, Kolegium biskupów a jedność Kościoła w nauczaniu Jana Pawła II, „Studia Warmińskie" 47 (2010), s. 224, 225.

17 J. Dyduch, Konferencja Biskupów w świetle motu proprio „Apostolos suos”, „Prawo Kanoniczne" 41 (1998) 3-4, s. 70.

18 Nowością wprowadzoną przez Jana Pawła II w liście o prawnej i teologicznej naturze episkopatu Apostolos suos jest udział konferencji biskupiej w spełnianiu nauczycielskiego zadania Kościoła (Jan Paweł II, list Apostolos suos, 21). „Chociaż biskupi, pozostający we wspólnocie z głową Kolegium i członkami, czy to pojedynczy, czy też zebrani na Konferencjach Episkopatu lub na synodach partykularnych, nie posiadają nieomylności w nauczaniu, są jednak w odniesieniu do wiernych powierzonych ich trosce autentycznymi nauczycielami i mistrzami wiary. Temu autentycznemu przepowiadaniu swoich biskupów wierni obowiązani są okazać religijne posłuszeństwo" (KPK, kan. 753). 
znanych, najczęściej używanych form przepowiadania kościelnego, o wyrazistym kształcie gatunkowym i funkcjach należy list pasterski. Jest to pismo biskupa lub episkopatu danego kraju skierowane do kapłanów lub świeckich z danej diecezji bądź kraju. Jego adresatami mogą być osoby indywidualne lub grupy osób, a poruszana w nich tematyka jest niezwykle różnorodna ${ }^{19}$.

Listy pasterskie poszczególnych episkopatów są eksponowanym głosem hierarchicznych przedstawicieli Kościoła lokalnego. Stanowią szczególną formę nauczania wiernych przez posługę słowa pisanego, które podlega wielokrotnej reprodukcji oraz układa się w zespół dokumentów życia Kościoła lokalnego, do których lektury można powracać, nawet po latach ${ }^{20}$. Listy pasterskie „służą szczegółowemu omówieniu niektórych zasad wiary lub obyczajów, zagadnień teologicznych lub duszpasterskich o dużym znaczeniu społecznym w aspekcie konkretnych okoliczności i potrzeb diecezji" ${ }^{21}$. Listy pasterskie poszczególnych episkopatów są adresowane zasadniczo do katolików w danych krajach, pełnią również funkcję wiarygodnego źródła orientacji w aktualnym stanowisku nauki chrześcijańskiej na temat danej problematyki dla społeczności spoza wspólnoty eklezjalnej ${ }^{22}$.

\section{Bezpośredni zwrot do poszukujących Boga}

Przepowiadanie słowa Bożego kierowane jest do konkretnych osób i wspólnot. Obecnie dostrzega się pilną potrzebę docierania ze słowem Bożym do osób dystansujących się od Kościoła i religii. Przykładem bezpośredniego zwrotu do człowieka zsekularyzowanego, a w tym przypadku już niewierzącego, jest list papieża Franciszka, opublikowany

19 Z. Kijas, Funkcje wypowiedzi Urzędu Nauczycielskiego Kościoła. Spojrzenie teologa, w: Funkcje wypowiedzi religijnych, red. R. Przybylska, W. Przyczyna, Tarnów 2014, s. 33, 34.

20 J. Duchniewski, Listy pasterskie, w: Encyklopedia katolicka, t. 10, red. A. Bednarek i in., Lublin 2004, kol. 1161-1162.

${ }^{21}$ J. Duchniewski, Listy pasterskie, dz. cyt., kol. 1161-1162.

22 G. Kubski, Listy episkopatu Polski w ujęciu teologicznym, w: Funkcje wypowiedzi religijnych, dz. cyt., s. 211. 
11 września 2013 roku we włoskim dzienniku „La Repubblica” do założyciela tej gazety Eugenia Scalfariego ${ }^{23}$. Jest to odpowiedź na zamieszczone w tej gazecie 7 lipca i 7 sierpnia 2013 roku artykuły Scalfariego, w których zadał on papieżowi kilka pytań. W liście do Scalfariego, który deklaruje się jako niewierzący, papież wyraził przekonanie, że „będzie rzeczą niewątpliwie pozytywną, nie tylko dla nas jako jednostek, ale też dla społeczeństwa, w którym żyjemy, jeżeli podejmiemy dialog na temat tak ważnej rzeczywistości jak wiara, która odwołuje się do nauczania i postaci Jezusa" ${ }^{24}$. Papież w liście opublikowanym na łamach lewicowego włoskiego dziennika zaznacza: „to właśnie na podstawie tego osobistego doświadczenia wiary, przeżytego w Kościele, mogę swobodnie wysłuchać Pana pytań i próbować, razem z Panem, szukać dróg, których przynajmniej pewien odcinek moglibyśmy pokonać razem”25.

Próba odpowiedzi na pytania zadawane przez współczesnego człowieka poszukującego Boga podejmowana jest również przez tzw. „dziedziniec pogan”. Podczas przemówienia do Kurii Rzymskiej wygłoszonego 21 grudnia 2009 roku papież Benedykt XVI zaznaczył: „Kościół powinien także dziś otworzyć jakiś rodzaj dziedzińca pogan, gdzie ludzie mogliby w jakiś sposób «uczepić» się Boga, nie znając Go i zanim odnajdą dostęp do Jego tajemnicy, której służy życie wewnętrzne Kościoła. Do dialogu z innymi religiami powinno się dziś dołączyć szczególnie dialog z tymi, dla których religia jest czymś obcym, którzy nie znają Boga, a którzy mimo wszystko nie chcieliby zostać po prostu bez Boga, lecz pragnęliby się do Niego przybliżyć, choćby jako do Nieznanego"26. W odpowiedzi na ten apel Papieska Rada do spraw Kultury utworzyła specjalną strukturę nazwaną właśnie „Dziedzińcem pogan”. Celem tego przedsięwzięcia jest spotkanie ludzi wierzących z niewierzącymi i podejmowanie dialogu dotyczącego wspólnych problemów ludzkości, takich

${ }^{23}$ Franciszek, List do niewierzacego, http://www.cl.opoka.org.pl/artykuly/volantino09 2013pl. pdf (01.09.2017).

${ }^{24}$ Franciszek, List do niewierzacego.

25 Franciszek, List do niewierzacego.

26 Benedykt XVI, Przemówienie do Kurii Rzymskiej (21 grudnia 2009), „Acta Apostolicae Sedis" 102 (2010), s. 40. 
jak sens życia, dobro i zło, rola miłości, sens cierpienia, prawa człowieka, sprawiedliwośćc7. Uznano, że „najlepszą płaszczyzną dialogu wierzących z niewierzącymi są trzy transcendentalia: prawda, dobro i piękno. Są one uniwersalnymi, ogólnoludzkimi wartościami i każdy człowiek ich poszukuje, bez względu na to, w co wierzy lub nie wierzy"28. Ludzkie pragnienie i pytania dotykają również dziedziny najistotniejszej, Boga. Pytania te zadają zarówno ludzie wierzący, przeżywający kryzysy wiary, jak i niewierzący. Benedykt XVI zwrócił się jednocześnie do wszystkich tych grup: „Niewierzący, chcecie zapytać wierzących, zwłaszcza wymagając od nich świadectwa życia, zgodnego z tym, co wyznają, i odrzucając wszelkie wypaczenia religii, które czyniłyby ją nieludzką. Wierzący, chcielibyście powiedzieć swym przyjaciołom, że ten skarb, który jest w was, zasługuje na to, by się nim dzielić, na refleksję. Pytanie o Boga nie jest zagrożeniem dla społeczeństwa, nie zagraża życiu ludzkiemu! Pytanie o Boga nie może być nieobecne między wielkimi pytaniami naszych czasów"29.

Sugestie dotyczące przepowiadania słowa Bożego w środowisku oddalonych od Kościoła i religii zawierają również dokumenty Konferencji Episkopatu Polski. KEP 28 listopada 2003 roku zatwierdziła dokument Dialog - zadanie na nowy wiek ${ }^{30}$. Biskupi polscy zachęcają w tym dokumencie do umacniania postaw dialogu w Polsce. Odwołując się do dialogu wewnątrz Kościoła i w relacji do społeczności świeckiej, zachęcają do uczenia się wzajemnego słuchania w cierpliwości i pokorze. W dokumencie biskupi zachęcają do szacunku wobec człowieka, który określa się jako niewierzący i niekiedy manifestuje swą niechęć do Kościoła. Niedopuszczalne jest przekreślanie takiego rozmówcy, wobec którego „również obowiązuje nas zasada miłości bliźniego, szukania płaszczyzny zrozumienia i dialogu. Bądźmy zdolni okazać gotowość do współpracy

27 P. Mąkosa, Dziedziniec pogan przestrzenią spotkania i dialogu wierzacych z niewierzacymi, „Przegląd Homiletyczny” 16 (2012), s. 81, 82.

28 P. Mąkosa, Dziedziniec pogan przestrzenia spotkania..., dz. cyt., s. 84.

${ }_{29}$ Benedykt XVI o laickości $i$ „Dziedzińcu pogan”: https://www.deon.pl/religia/kosciol-i-swiat/z-zycia-kosciola/art,5085, benedykt-xvi-o-laickosci-i-dziedzincu-pogan.html (02.09.2017).

30 http://www.kuria.lomza.pl/index.php?wiad=598 (03.09.2017). 
tam, gdzie uznajemy i możemy rozwijać wspólne wartości, poznawać prawdę, podziwiać piękno i pomnażać dobro"31.

Kolejnym dokumentem, który bezpośrednio odwołuje się do duszpasterskiego posługiwania wśród osób niewierzących, jest pismo Niewierzacy w parafii - sugestie duszpasterskie ${ }^{32}$ opublikowany 16 kwietnia 1999 roku przez Komitet ds. Dialogu z Niewierzącymi Rady Konferencji Episkopatu Polski ds. Dialogu Religijnego ${ }^{33}$. W dokumencie biskupi postulują „wprowadzenie do programu duszpasterskiego problematyki ewangelizacji ludzi niewierzących, a także zwrócenie uwagi na problem stosunku do niewierzacych w kontaktach pastoralnych. Nie bez znaczenia jest także sprawa działań zmierzających do zahamowania procesu odchodzenia ludzi od wiary"34.

Dialog z człowiekiem niewierzącym czy wątpiącym nie powinien zaczynać się od prób nawracania, gdyż często takie zachowanie jest odczytywane jako próba zamachu na wolność. Zalecane jest natomiast

31 http://www.kuria.lomza.pl/index.php?wiad=598 (03.09.2017).

32 Zob. M. Fiałkowski, Troska Kościoła o niewierzacych. Na marginesie dokumentu pt. „Niewierzacy w parafii -sugestie duszpasterskie”, w: W prostocie prawdy, w pokorze miłości. Studia i materiały dedykowane Księdzu prof. zw. dr. hab. Janowi Walowi, red. T. Borutka, A. Baczyński, M. Ostrowski, Kraków 2008, s. 243-251.

33 Komitet ds. Dialogu z Niewierzącymi Rady Konferencji Episkopatu Polski ds. Dialogu Religijnego, Niewierzacy w parafii - sugestie duszpasterskie, http://www.currenda.diecezja.tarnow.pl/ archiwum/2-00/kep-2.htm (03.09.2017).

${ }_{34}$ W dokumencie wyróżnione zostają pewne kategorie niewierzących: ateiści, a więc ludzie o sprecyzowanym systemie myślowym i określonej filozofii życiowej; niewierzący, których niewiara wywodzi się z życiowych doświadczeń lub niemożności pogodzenia swego życia z wymaganiami wiary; obojętni religijnie, którzy dali się opanować materializmowi praktycznemu, oraz wątpiący i poszukujący. Wśród najbardziej narażonych na utratę wiary dokument wymienia młodzież szkół ponadpodstawowych i wyższych, kobiety mające na sumieniu zabicie dziecka nienarodzonego, uwikłanych w alkoholizm i narkomanię, odchodzących od wiary z racji kariery politycznej czy zawodowej oraz środowisko inteligenckie, zwłaszcza inteligencji twórczej, która w tej chwili w dużym procencie dystansuje się od Kościoła. Następnie wymienione są okoliczności spotkania duszpasterzy z osobami niewierzącymi. To najczęściej chrzest i I Komunia Święta dziecka, ślub i pogrzeb bliskiej osoby. Do spotkań takich może dojść również przy okazji wizyty duszpasterskiej, załatwiania spraw w różnych instytucjach czy urzędach, a także w relacjach towarzyskich. Spotkania te mogą mieć wielkie znaczenie dla życia tych ludzi i mogą stanowić okazję do prowadzenia ewangelizacji. Komitet ds. Dialogu z Niewierzącymi Rady Konferencji Episkopatu Polski ds. Dialogu Religijnego, Niewierzacy w parafii - sugestie duszpasterskie. 
dzielenie się własnym doświadczeniem wiary, ukazywanie jej racjonalnych przesłanek. Człowiek wątpiący i niewierzący oczekuje przede wszystkim osobistego świadectwa rozmówcy, a w dalszej kolejności pouczenia o wierze, odpowiedzi na pytania o zasady wiary.

Bezpośredni kontakt i oddziaływanie na człowieka zsekularyzowanego następuje głównie przez tak zwane duszpasterstwo zwyczajne, związane z głoszeniem słowa Bożego i sprawowaniem sakramentów. Wymienione wcześniej okoliczności powinny być okazją do głoszenia słowa Bożego, które jest „wierne Ewangelii Jezusa Chrystusa. Wielu ludzi skarży się, że podczas niedzielnej Eucharystii słowo Boże jest głoszone niedbale, bez przygotowania, a sama Eucharystia sprawowana z pośpiechem, bez świadomości, że jest to tajemnica śmierci i zmartwychwstania Chrystusa" ${ }^{35}$.

\section{Listy pasterskie biskupów Włoch i Francji - powstanie i charakterystyka}

Przykładem bezpośredniego zwrotu do osób niewierzących, jak również wierzących, ale w znacznym stopniu już zsekularyzowanych, mogą być listy biskupów Francji: Proposer la foi dans la société actuelle (Proponować wiarę we wspótczesnym społeczeństwie) i Włoch: Lettera ai cercatori di Dio (List do poszukujących Boga).

List biskupów Francji do katolików francuskich Proponować wiarę we wspótczesnym spoleczeństwie tworzono w kilku etapach, na przestrzeni lat 1994-1996, co miało istotny wpływ zarówno na jego strukturę, jak i treść. Na początkowym etapie przedstawiony został raport zredagowany przez tak zwaną grupę roboczą, na czele której stanął Claude Dagens - biskup diecezji Angouleme. Następnie biskupi francuscy skierowali apel do wszystkich, którzy chcą wziąć aktywny udział w biskupich poszukiwaniach, o nadesłanie uwag i sugestii. Raport miał być nie tyle oceną sytuacji, ile sposobem rozeznania wyzwań, jakie niosą nowe warunki dla wiary i Kościoła. Wyrażono przekonanie, że w dwudziestą

35 Komitet ds. Dialogu z Niewierzącymi Rady Konferencji Episkopatu Polski ds. Dialogu Religijnego, Niewierzacy w parafii - sugestie duszpasterskie. 
rocznicę ukazania się adhortacji apostolskiej Evangelii nuntiandi (1975) Kościół we Francji wezwany jest do wypracowania swoistej „karty ewangelizacji" na obecne czasy. Poddano szerokiej konsultacji kolejne wersje raportu, by 8 listopada 1996 roku zatwierdzić trzecią i ostateczną wersję. Episkopat Francji zaaprobował go pod oficjalnym tytułem: Proposer la foi dans la société actuelle w formie listu: Lettre aux catholiques de France ${ }^{36}$. Dokument ukazuje znaczną „ewaluację roli i miejsca Kościoła katolickiego we Francji - kraju, gdzie chrześcijaństwo zepchnięte zostało do przestrzeni życia osobistego" ${ }^{37}$. List do francuskich katolików jest inspirowany przekonaniem, że Kościół żyje dla wiary, do której, poprzez czasy i miejsca, nieustannie otwiera ludziom drogę $e^{38}$. List podejmuje trzy zasadnicze zagadnienia. W pierwszej części listu, zatytułowanej Comprendre notre situation de catholiques dans la société actuelle (Zrozumieć naszą sytuację katolików w społeczeństwie aktualnym) autorzy stawiają sobie za cel pomoc ludziom wierzącym we Francji w odnalezieniu się w obecnej sytuacji oraz zachętę do przyjęcia odpowiedniej postawy chrześcijańskiej. Na współczesną sytuację Kościoła katolickiego wpłynęły trzy istotne fakty: laickość państwa, pluralizm religijny oraz nowa relacja pomiędzy Kościołem katolickim a państwem (LCF, s. 7-11) ${ }^{39}$. Część druga, Aller au coeur du mystère de la foi (Skierować się ku sercu tajemnicy wiary), zawiera trzy propozycje skierowane do współczesnych katolików, żyjących w środowisku zsekularyzowanym: 1) konieczność pełniejszego zaufania Bogu Jezusa Chrystusa, który jest zbawieniem na dziś i na zawsze; 2) postulat stawiania czoła doświadczanemu złu, między innymi poprzez zrozumienie, że utrapienia obecnego czasu gotują bezmiar chwały przyszłego wieku (LCF, s. 22); 3) postulat życia i działania według Ducha, czyli wiązania kerygmatu z etyką i wiary z działaniem, to bowiem prowadzi

36 J. Plech, „Proponować wiarę we współczesnym społeczeństwie”. Postulaty pastoralne dla Kościoła lokalnego na podstawie listu biskupów Francji do katolików francuskich, „Teologia Praktyczna" 3 (2002), s. 59-62.

37 M. H. Robert, La mission en France selon la Lettre des évêques aux catholiques de France (1996) et ses prolongements, „Nurt SVD” 44 (2010) 2, s. 171.

38 J. Plech, „Proponować wiarę we współczesnym społeczeństwie”. Postulaty pastoralne..., dz. cyt., s. 62 .

39 Podane strony odnoszą się do internetowej wersji dokumentu, http://ec.cef.fr/wp-content/uploads/sites/2/2014/05/dagens.pdf (01.09.2017). 
do odnowy moralności chrześcijańskiej (LCF, s. 22-26). Trzecia część listu, nosząca tytuł: Former une Eglise qui propose la foi (Formować Kościót, który proponuje wiarę), ma charakter pastoralno-praktyczny. Treść tej części listu, odwołująca się także do konkretnych działań skierowanych w stronę ludzi poszukujących Boga, zostanie omówiona w następnym punkcie niniejszego opracowania.

Za bezpośredni zwrot do osób zsekularyzowanych można uznań opublikowany przez biskupów włoskich w Niedzielę Zmartwychwstania Pańskiego 2009 roku Lettera ai cercatori di Dio (List do osób poszukujacych Boga). List został zredagowany w 2008 roku przez Komisję Episkopatu Włoch do spraw Doktryny Wiary, Głoszenia i Katechezy. Zatwierdzony przez Radę Stałą Konferencji Episkopatu Włoch we wrześniu 2008 roku, opatrzony słowem wstępnym arcybiskupa Bruna Fortego, przewodniczącego komisji episkopatu redagującej dokument, został podpisany 12 kwietnia 2009 roku $^{40}$. Dokument będący owocem kolegialnej pracy biskupów, teologów, duszpasterzy, katechetów i ekspertów do spraw komunikacji pastoralnej powinien być, zgodnie z zamierzeniami autorów, przede wszystkim pomocą, skierowaną do wszystkich ludzi szukających Boga, zainteresowanych pytaniem o Jego istnienie i działanie. We wstępie do dokumentu arcybiskup Bruno Forte wskazuje na grono jego adresatów, którymi są zarówno osoby niewierzące, które zauważają powagę pytań o Boga, osoby wierzące, zadające sobie ciągle nowe pytania oraz osoby, które w żaden sposób nie są zainteresowanie problemem Boga, które znajdą w liście refleksję nad sensem życia oraz wątpliwościami sumienia dotyczącymi rzeczywistości transcendentnej i spraw ostatecznych ${ }^{41}$.

40 W. Osial, Konferencja Episkopatu Włoch, Komisja ds. Doktryny Wiary, Głoszenia i Katechezy, Lettera ai cercatori di Dio, Rzym, 12 kwietnia 2009, „Katecheta” 54 (2010) 3, s. 85.

41 B. Forte, Presentazione, w: Commisione Episcopale per la Dottrina della Fede, L'annuncio e la catechesi della Conferenza Episcopale Italiana, Lettera ai cercatori di Dio, dz. cyt., s. 1. 


\section{Słowo do poszukujących Boga w listach biskupów Włoch i Francji}

List biskupów Francji do katolików francuskich Proponować wiarę we wspótczesnym społeczeństwie, chociaż explicite nie zawiera zwrotu do niewierzących ani też do poszukujących Boga, podaje liczne wskazówki, jak na nowo „zaproponować wiarę”, nie nakazując czegokolwiek. „Potrójna misja ochrzczonych: wyznanie wiary, troska o dobro ludzkości, praktyka liturgiczna i sakramentalna - stanowi podstawową i niezastąpioną formę oddziaływania na zlaicyzowane społeczeństwo" ${ }^{42}$. Propozycja wiary powinna być zakorzeniona w ludzkiej egzystencji, odwołując się do ludzkich pytań, wątpliwości, potrzeb, pragnień, trudności i poszukiwań. Trzecia część listu: Formować Kościót, który proponuje wiarę, ma charakter pastoralno-praktyczny i formułuje konkretne projekty, postulaty umożliwiające głoszenie Ewangelii Chrystusa. Pierwszym postulatem jest systematyczny rozwój doświadczenia ewangelizacji, bowiem działalność ewangelizacyjna wzywa do pogłębiania wiary i komunii, która daje podstawę istnienia Kościoła, a uprzywilejowanym terenem ewangelizacji jest teren ludzkiej egzystencji (LCF, s. 26-30). Konieczność formowania Kościoła, który jest sakramentem Chrystusa we współczesnym społeczeństwie, jest postulatem drugim. To formowanie Kościoła związane jest z koniecznością rozumienia przez ludzi ochrzczonych istoty Kościoła i jego sakramentalności oraz zadań Kościoła w służbie społeczeństwu (LCF, s. 30-33) $)^{43}$.

Trzeci postulat, podejmujący zagadnienia związane z problematyką niniejszego opracowania, wskazuje na konieczność sprecyzowania linii działania. Postulat odwołuje się do sposobów samourzeczywistniania się Kościoła poprzez: celebrację tajemnicy zbawienia (liturgia), służbę ludzkiemu życiu (diakonia) oraz głoszenie Ewangelii (martyria). Liturgia i doświadczenie Boga w liturgii jest „wejściem w serce wiary”

\footnotetext{
${ }^{42}$ M. H. Robert, La mission en France..., dz. cyt., s. 71.

43 J. Plech, „Proponować wiare we współczesnym społeczeństwie”. Postulaty pastoralne..., dz. cyt., s. 74, 75 .
} 
i ,zaczynem dla prawdziwego nawrócenia i odnowy wiary” ${ }^{44}$. W wymiarze życia sakramentalnego proponuje się uzupełnienie „duszpasterstwa przyjmowania” "duszpasterstwem propozycji” i zaproszeniem do spotykania Chrystusa w sakramentach. W wymiarze diakonii osobom zaangażowanym powinno towarzyszyć przekonanie, że służba drugiemu człowiekowi jest wypełnieniem chrześcijańskiego powołania oraz formą głoszenia Ewangelii. Zaś w wymiarze posługi słowa, martyrii, czyli działalności ożywiającej wzrost wiary i Kościoła, postuluje się właściwą formację doktrynalną i teologiczną, co powinno przyczynić się do skuteczniejszego głoszenie wiary (LCF, s. 34-39) ${ }^{45}$. List biskupów francuskich do katolików we Francji ukazuje „prosty i zdecydowany” sposób proponowania wiary człowiekowi współczesnemu, wskazując na jej nowość ewangeliczną i potwierdzając jej wartość świadectwem własnego nawrócenia. Propozycja przyjęcia Ewangelii nie oznacza kontrpropozycji kulturowej czy społecznej, ale wnoszenie w sferę społeczną mocy Ducha skłaniającej innych do powrotu do Boga ${ }^{46}$.

Autorzy dokumentu Lettera ai cercatori di Dio, przygotowanego przez Konferencję Episkopatu Włoch, kierują go do tych, którzy uznają się za Bożych pielgrzymów, szukając oblicza Pana, oraz do tych, którzy są w trakcie poszukiwania genezy ludzkiego życia, jego nowego sensu i ostatecznego horyzontu. Zadaniem listu jest wzbudzenie wiary w ludziach szukających Boga oraz pogłębienie wiary u osób przeżywających jej kryzys.

Zdaniem autorów listu poszukującym Boga jest każdy człowiek wierzący, bo w gruncie rzeczy każdy wierzący jest ateistą, który każdego dnia stara się wierzyć od nowa. Bowiem każdy, kto wierzy, ma potrzebę codziennego odnowienia swojego spotkania z Bogiem, karmiąc się ze źródła modlitwy i słuchania objawionego Słowa (LcD, s. 18) ${ }^{47}$.

44 A. Sielepin, Współczesny katechumenat dorosłych w procesie formowania wiary, „Przegląd Homiletyczny" 16 (2012), s. 92.

45 J. Plech, „Proponować wiarę we wspótczesnym społeczeństwie”. Postulaty pastoralne..., dz. cyt., s. 77.

46 S. Zarzycki, Wzajemna relacja pomiędzy kulturą a wiarą i duchowością chrześcijańską - rys historyczny, „Roczniki Teologiczne” 64 (2017) 5, s. 38, 39.

${ }_{47}$ Podane strony odnoszą się do internetowej wersji dokumentu, http://www.chiesacattolica.it/documenti-segreteria/lettera-ai-cercatori-di-dio (01.09.2017). 
W pierwszym rozdziale dokumentu Le domande che ci uniscono (Pytania, które nas jednocza) (LcD, s. 4-19) autorzy wskazują na najgłębsze egzystencjalne pytania i dylematy człowieka ponowoczesnego i zarazem staraja się dać właściwą, wynikającą z objawienia odpowiedź. Wśród zagadnień fundamentalnych znalazły się pytanie o szczęście i cierpienie, o sztukę miłowania, o sens czasu pracy i świętowania, o sprawiedliwość i pokój. Ostatnim pytaniem, które zdaje się jednoczyć wszystkich szukających sensu, jest pytanie będące fundamentem wszystkich ludzkich pytań, pytanie o samego Boga (LCD, s. 16-19) $)^{48}$. Pytania te zachęcają do zajrzenia w najgłębsze tajniki serca człowieka, a jednocześnie powinny ułatwić człowiekowi odkrycie potrzeby spotkania z Bogiem ${ }^{49}$.

Drugi rozdział dokumentu: La speranza che è in noi (Nadzieja, która jest $w$ nas) (LCD, s. 21-38) jest centralnym punktem listu. Bóg ukazany jest jako sens historii i życia ludzkiego, a doświadczenie wiary w Boga pomaga udzielać odpowiedzi na pytania i poszukiwania człowieka. Autorzy listu przybliżają czytelnikom prawdę o objawieniu się Boga w Jezusie Chrystusie, tajemnicę Kościoła oraz wzywają do życia według Ducha. Jezus Chrystus jest Tym, który w ziemskim doświadczeniu przeżył wszystkie troski i niepokoje obecne w życiu współczesnego człowieka. Poszukujący Boga znajdą w tym punkcie dokumentu zachętę do przemyślenia nauki Jezusa Chrystusa oraz zainteresowania się świadectwami Jego działalności.

Rozdział trzeci dokumentu: Come incontrare il Dio di Gesù Cristo (Jak spotkać Boga, Jezusa Chrystusa?) (LcD, s. 39-55) zawiera konkretne sugestie, mające na celu udzielenie pomocy szukającym Boga. Dojście do osobistego spotkania z żywym Bogiem powinno być wynikiem namysłu, planowania i przeżycia konkretnych egzystencjalnych doświadczeń. W kolejnych punktach dokument wskazuje te doświadczenia, które pozwalają odkryć Boga i podtrzymać zażyłość z Nim, czyli: modlitwę, słuchanie słowa Bożego, sakramenty, służbę Bogu i bliźniemu oraz wierne

48 W. Surmiak, „O poszukujacych Boga”. Pytania człowieka ponowoczesnego w świetle dokumentu Konferencji Episkopatu Włoch, zatytułowanego Lettera ai cercatori di Dio, „Studia Pastoralne” 6 (2010), s. 323-333.

49 W. Osial, Konferencja Episkopatu Włoch..., dz. cyt., s. 85, 86. 
oczekiwanie na przyszłe życie. Istotną rolę w odkrywaniu Boga oraz wzrastaniu w wierze ma wspólnota Kościoła, która podtrzymuje i dodaje odwagi na drodze wiary, pomaga przyjąć i interpretować prawdę życia ludzkiego oraz otwierać się na Boga. Autorzy listu proponują czytelnikom swego rodzaju mapę życia, prowadzonego według Ducha Bożego. Mo ona pomóc wzbudzić większą ufność w bliskość i działanie Boga w codziennym życiu człowieka (LcD, s. 40) ${ }^{50}$.

Analizowany dokument nie ma na celu przekazania całości chrześcijańskiej doktryny. Zainteresowanych pogłębieniem treści zasygnalizowanych w liście odsyła do dalszej lektury publikacji wprowadzających w chrześcijaństwo. Są nimi Katechizm Kościoła katolickiego oraz katechizmy Konferencji Episkopatu Włoch, a także dzieła teologów: Josepha Ratzingera, Waltera Kaspera, Karla Rahnera, Hansa Ursa von Balthasara, Natale Bussiego i Bruna Fortego (LcD, s. 55).

W treści i formie dokumentu wyraźnie widoczne są szacunek i życzliwość, z jakimi autorzy odnoszą się do wszystkich ludzi szukających Boga, to ciepłe i przyjazne zaproszenie do poszukiwania Boga, który daje się odnaleźć. Treści egzystencjalne i antropologiczne, odwoływanie się do licznych wydarzeń i sytuacji z zakresu codzienności życia ludzkiego czynią dokument bardzo jasnym i czytelnym. Ewangelizacyjne założenia listu pozwoliły uniknąć trudnych do zrozumienia interpretacji teologicznych i przyczyniły się do łatwiejszej percepcji treści dokumentu ${ }^{51}$.

Dokument Lettera ai cercatori di Dio stanowi cenną podpowiedź dla głosicieli słowa Bożego na temat zasadniczej problematyki przepowiadanego słowa Bożego. Każdy poszukujący Boga zadaje stałe i powtarzające się pytania, zaś różnica pomiędzy wierzącym i niewierzącym nie polega na myśleniu czy niemyśleniu o Bogu, bowiem wiara jest przede wszystkim darem łaski. Fundamentalne ludzkie pytania o cierpienie i szczęście, o sens pracy i odpoczynku, o sztukę miłowania, o sprawiedliwość i pokój, i ostatecznie o samego Boga powinny stać się treścią kaznodziejskiego przepowiadania słowa Bożego ${ }^{52}$.

50 W. Osial, Konferencja Episkopatu Włoch..., dz. cyt., s. 86, 87.

${ }_{51}$ W. Osial, Konferencja Episkopatu Włoch..., dz. cyt., s. 87.

52 W. Surmiak, „O poszukujących Boga”. Pytania człowieka..., dz. cyt., s. 320. 


\section{Podsumowanie}

Ludzie poszukujący Boga nie szukają nieokreślonego projektu życia i poczucia bezpieczeństwa, ale Kogoś, kto może stać się największą miłością życia ${ }^{53}$. Bowiem Bóg nie jest tylko łatwą odpowiedzią na ludzkie potrzeby, ale odpowiedzią na pragnienie spotkania się z odwiecznym In n y m, który pomaga zrozumieć samego siebie. Często osobista wiara jest bardziej tęsknotą aniżeli chęcią zrozumienia i wyjaśnienia wszystkiego za wszelką cenę.

Próbę bezpośredniego dotarcia do osób niewierzących, do poszukujących Boga oraz do wierzących, ale w znacznym stopniu już zsekularyzowanych podjęli biskupi Francji w liście Proponować wiarę we wspótczesnym społeczeństwie i Włoch w Liście do poszukujących Boga. Chociaż od ich wydania minęło już odpowiednio 20 i 8 lat, to dokumenty nadal są aktualne i stanowią konkretną pomoc dla osób poszukujących Boga.

Również w Polsce, gdzie grupa ludzi poszukujących odpowiedzi na fundamentalne pytania, w tym pytania o Boga, jest niemała, podobny dokument byłby bardzo wskazany ${ }^{54}$. Często osoby te niejako „po omacku" same szukają Boga w swoim życiu. Autorem takiego listu mogą być Konferencja Episkopatu Polski, miejscowy biskup lub duszpasterze parafialni. List do ludzi słabo związanych z Kościołem, z zaproszeniem do wspólnoty wierzących i wyjaśnieniem podstawowych prawd wiary, stanowiłby realizację fundamentalnego zadania Kościoła, który stara się wciąż na nowo odpowiadać na wezwanie Jezusa Chrystusa: „Idźcie na cały świat i nauczajcie wszystkie narody...” $($ Mt 28, 19).

53 W. Surmiak, „O poszukujacych Boga”. Pytania człowieka..., dz. cyt., s. 334.

54 W. Śmigiel, Wizyta duszpasterska, zwana kolęda, jako szansa na ewangelizację osób dystansujacych się od Kościoła, „Teologia Praktyczna” 14 (2013), s. 120. 


\section{Summary}

\section{Treść przepowiadania do poszukujących Boga na przykładzie listów pasterskich biskupów Francji i Włoch}

Pytanie o istnienie Boga, możliwość nawiązania z Nim kontaktu i ewentualny wpływ Boga na życie człowieka nurtuje ludzi już od wieków. W niniejszym opracowaniu podjęty został problem treści przepowiadania do poszukujących Boga. W pierwszej części opracowania omówione zostało zagadnienie podstawowego zadania biskupa, którym jest głoszenie słowa Bożego. W dalszej kolejności przedstawione zostały inicjatywy mające na celu bezpośredni zwrot do osób poszukujących Boga. Przykładem bezpośredniego zwrotu do osób niewierzących, jak również poszukujących Boga, mogą być listy biskupów Francji - Proponować wiarę we współczesnym społeczeństwie i Włoch - List do poszukujących Boga. Omówienie etapów ich powstawania i zarysowanie ogólnej charakterystyki oraz analiza treści są kolejnymi elementami treści niniejszego opracowania.

Słowa kluczowe: treść przepowiadania, przepowiadanie dla poszukujących Boga, biskup, list pasterski

\section{The Content of Preaching to the Searching for God Exemplified in Pastoral Letters of Bishops of France and Italy}

The question concerning the existence of God, possibility to contact Him and a potential influence of God on human life has intrigued mankind for ages. This work focuses on the issue of the content of preaching to the searching for God. The first part of the work includes an analysis of the major task of a bishop, which is preaching the word of God. Further on the author presents initiatives aiming at a direct approach to the searching for God. An example of a direct approach to individuals who do not believe in God and the ones who are searching for Him are letters of bishops of France - Suggesting faith in the contemporary society and Italy A letter to the searching for God. Analysis of stages of their writing and outline of their general characteristics as well as content analysis are consecutive parts of this study.

Keywords: content of preaching, preaching to the searching for God, bishop, pastoral letter 


\section{Bibliografia}

Benedykt XVI o laickości i „dziedzińcu pogan", http://www.deon.pl/religia/kosciol-i-swiat/z-zycia-kosciola/art,5085, benedykt-xvi-o-laickosci-i-dziedzincu- pogan.html. (02.09.2017).

Benedykt XVI, Przemówienie do Kurii Rzymskiej (21 grudnia 2009), „Acta Apostolica Saedis" 102 (2010), s. 40.

Commisione Episcopale per la dottrina della fede, l'annuncio e la catechesi della Conferenza Episcopale Italiana, Lettera ai cercatori di Dio, Roma 2009.

Duchniewski J., Listy pasterskie, w: Encyklopedia katolicka, t. 10, red. A. Bednarek i in., Lublin 2004, kol. 1161-1162.

Dyduch J., Konferencja Biskupów w świetle motu proprio „Apostolos suos”, „Prawo Kanoniczne" 41 (1998) 3-4, s. 59-74.

Dyduch J., Kształt prawny Konferencji Episkopatu Polski, „Prawo Kanoniczne” 56 (2013) 2, s. 3-15.

Fiałkowski M., Troska Kościoła o niewierzacych. Na marginesie dokumentu pt. „Niewierzacy w parafii - sugestie duszpasterskie”, w: W prostocie prawdy, w pokorze miłości. Studia i materiały dedykowane Księdzu prof. zw. dr. hab. Janowi Walowi, red. T. Borutka, A. Baczyński, M. Ostrowski, Kraków 2008, s. 243-251.

Forte B., Presentazione, w: Commisione Episcopale per la Dottrina della Fede, L'annuncio e la catechesi della Conferenza Episcopale Italiana, Lettera ai cercatori di Dio, Roma 2009.

Franciszek, List do niewierzacego, http://www.cl.opoka.org.pl/artykuly/volantino09 2013pl. pdf (01.09.2017).

Kijas Z., Funkcje wypowiedzi Urzędu Nauczycielskiego Kościoła. Spojrzenie teologa, w: Funkcje wypowiedzi religijnych, red. R. Przybylska, W. Przyczyna, Tarnów 214, s. 33-48.

Komitet ds. Dialogu z Niewierzącymi Rady Konferencji Episkopatu Polski ds. Dialogu Religijnego, Niewierzacy w parafii. Sugestie duszpasterskie, http://www.currenda.diecezja. tarnow.pl/ archiwum/2-00/kep-2.htm (03.09.2017).

Kongregacja Nauki Wiary, Nota doktrynalna na temat pewnych aspektów ewangelizacji, „L'Osservatore Romano” wyd. pol. 29 (2008) nr 2, s. 50-51.

Kubski G., Listy episkopatu Polski w ujęciu teologicznym, w: Funkcje wypowiedzi religijnych, red. R. Przybylska, W. Przyczyna, Tarnów 214, s. 199-213.

Les Evêques de France, Proposer la foi dans la société actuelle, III. Lettre aux catholiques de France, Paris 1997.

Lukoszek M., Kolegium biskupów a jedność Kościoła w nauczaniu Jana Pawła II, „Studia Warmińskie" 47 (2010), s. 215-228.

Mąkosa P., Dziedziniec pogan przestrzenia spotkania i dialogu wierzących z niewierzacy$m i$, „Przegląd Homiletyczny” 16 (2012), s. 81-88.

Osial W., Konferencja Episkopatu Włoch, Komisja ds. doktryny wiary, głoszenia i katechezy, Lettera ai cercatori di Dio, Rzym, 12 kwietnia 2009, „Katecheta” 54 (2010) 3, s. 85-87. 
Osial W., Wezwanie Benedykta XVI do nowej ewangelizacji w świetle listu apostolskiegomotu proprio "Ubicumque et semper" ustanawiającego Papieska Radę ds. Krzewienia Nowej Ewangelizacji, „Warszawskie Studia Teologiczne” 24 (2011) 1, s. 277-290.

Plech J., „Proponować wiarę we wspótczesnym społeczeństwie”. Postulaty pastoralne dla Kościoła lokalnego na podstawie listu biskupów Francji do katolików francuskich, „Teologia Praktyczna" 3 (2002), s. 58-78.

Robert M. H., La mission en France selon la Lettre des évêques aux catholiques de France (1996) et ses prolongements, „Nurt SVD” 44 (2010) 2, s. 161-172.

Sielepin A., Wspótczesny katechumenat dorosłych $w$ procesie formowania wiary, „Przegląd Homiletyczny” 16 (2012), s. 89-104.

Siwek G., Przepowiadanie słowa Bożego, w: Teologia pastoralna, t. 1, red. R. Kamiński, Lublin 2002, s. 131-179.

Surmiak W., „O poszukujących Boga”. Pytania człowieka ponowoczesnego w świetle dokumentu Konferencji Episkopatu Włoch, zatytułowanego „Lettera ai cercatori di Dio” "Studia Pastoralne" 6 (2010), s. 320-334.

Szewczyk L., Biskup jako nauczyciel wiary $i$ herold słowa Bożego, w: Vobis Episcopus Vobiscum Christianus, red. W. Myszor, A. Malina, Katowice 2004, s. 155-162.

Szewczyk L., Odnowa przepowiadania słowa Bożego w (archi)diecezji katowickiej po Soborze Watykańskim II. Studium homiletyczne, Katowice 2009.

Śmigiel W., Wizyta duszpasterska, zwana kolęda, jako szansa na ewangelizację osób dystansujących się od Kościoła, „Teologia Praktyczna” 14 (2013), s. 113-121.

Zarzycki S., Wzajemna relacja pomiędzy kulturą a wiara i duchowością chrześcijańska rys historyczny, „Roczniki Teologiczne” 64 (2017) 5, s. 5-44. 